\title{
КІЛЬКІСНА МОРФОЛОГІЧНА ОЦІНКА СТРУКТУРНОЇ ПЕРЕБУДОВИ АРТЕРІЙ ПОРОЖНЬОЇ КИШКИ ПРИ ПОСТРЕЗЕКЦІЙНІЙ ПОРТАЛЬНІЙ ГІПЕРТЕНЗІЇ
}

\begin{abstract}
Резюме. Резекцію печінки широко застосовують у сучасних хірургічних відділеннях. Видалення великих об'ємів печінки призводить до пострезекційної портальної гіпертензії, що ускладнюється кровотечами з варикозно розширених вен стравоходу, шлунка, прямої кишки, асцитом, спленомегалією, вторинним гіперспленізмом, паренхіматозною жовтяницею та портосистемною енцефалопатією. Широка розповсюдженість даної патології, висока смертність від її ускладнень свідчать, що вона $€$ важливою медичною та соціальною проблемою.

Мета дослідження - кількісне морфологічне вивчення особливостей структурної перебудови артерій порожньої кишки при пострезекційній портальній гіпертензії.

Матеріали і методи. Дослідження проведено на 36 статевозрілих щурах-самцях, яких поділили на 3 групи: перша нараховувала 12 інтактних практично здорових тварин, друга - 12 щурів після резекції лівої бокової частки - 31,5 \% паренхіми печінки, третя - 12 щурів після видалення правої та лівої бокових часток печінки (58,1 \%). Евтаназію дослідних тварин здійснювали кровопусканням в умовах тіопенталового наркозу через місяць від початку експерименту. Із порожньої кишки виготовляли гістологічні мікропрепарати. Проводиди морфометрію артерій середнього (51-125 мкм) та дрібного калібрів (26-50 мкм), при якій вимірювали їх зовнішній, внутрішній діаметри, товщини медії та адвентиції, висоту ендотеліоцитів, діаметр їх ядер, визначали індекс Вогенворта, ядерно-цитоплазматичні відношення в ендотеліоцитах, відносний об'єм ушкоджених ендотеліоцитів. Кількісні показники обробляли статистично.

Результати досліджень та їх обговорення. Встановлено, що при резекції 31,5 \% паренхіми печінки досліджувані морфометричні показники артерій середнього та дрібного калібрів порожньої кишки змінювалися незначно. При видаленні 58,1 \% паренхіми печінки виявлено виражену структурну перебудову артеріального русла з домінуванням морфологічних змін у артеріях дрібного калібру порожньої кишки. Через місяць після видалення 58,1 \% паренхіми печінки зовнішній діаметр артерій дрібного калібру зріс на 2,0 \%, товщина медії - на 16,7 \%, товщина адвентиції - на 34,5 \%, індекс Вогенворта - у 1,4 раза, вказуючи на істотне порушення пропускної здатності досліджуваних судин. Просвіт артерій дрібного калібру при цьому з вираженою статистичною достовірністю ( $p<0,001)$ зменшився на 16,1 \%. Висота ендотеліоцитів даних судин виявилася зміненою на 9,6 \%, а діаметр ядер - на 5,4 \% (р<0,01). Ядерно-цитоплазматичні відношення в ендотеліоцитах досліджуваних артерій виявилися суттєво зміненими, що свідчило про порушення клітинного структурного гомеостазу, а відносний об'єм ушкоджених ендотеліоцитів при цьому зріс у 23,4 раза. Наведене свідчить про виражене ремоделювання артерій порожньої кишки при видаленні 58,1 \% паренхіми печінки, яке призводить до погіршання кровопостачання органа, гіпоксії, дистрофрії, некробіозу клітин і тканин, а пізніше інфільтративних та склеротичних процесів.

Висновки. Резекція 58,1 \% паренхіми печінки призводить до пострезекційної портальної гіпертензії та вираженої структурної перебудови артерій середнього та дрібного калібрів порожньої кишки, яка характеризується потовщенням їхньої стінки, звуженням просвіту, ураженням ендотеліоцитів, ендотеліальною дисфункцією, погіршанням кровопостачання органа, гіпоксією, дистрофрією, некробіозом тканин і клітин, вогнищевими клітинними інорільтратами, склерозуванням. Ступінь структурної перебудови артерій порожньої кишки при пострезекційній портальній гіпертензії залежить від їх калібру і найбільш вираженим виявився у досліджуваних судинах дрібного калібру.
\end{abstract}

Ключові слова: резекція печінки; порожня кишка; структура артерій; морфометрія.

ВСТУПУ хірургічних стаціонарах лікувальних закладів на сьогодні нерідко виконують резекцію печінки. Дану операцію здійснюють при доброякісних та злоякісних пухлинах, метастазах, травмах печінки, внутрішньопечінковому холангіолітіазі, альвеолярному ехінококозі, трансплантації печінки $[2,4,10]$. У сучасній медико-біологічній літературі зустрічаються публікації, де відображені результати експериментальних досліджень 3 вивчення паренхіми печінки при її резекції. Разом з тим, недостатньо досліджено структурні зміни у травному каналі при резекціях різних об'ємів печінки. Вирішення даного питання має не тільки важливе теоретичне значення, але набуває актуальності у клінічній практиці.

Резекція великих об'ємів паренхіми печінки призводить до складних загальнобіологічних процесів, які виникають і розвиваються при цьому в органах і системах організму при його адаптації до нового рівня життєдіяльності $[10,12]$. Необхідно зазначити, що детальне та об'єктивне знання компенсаторно-адаптаційних процесів у стінці порожньої кишки, її артеріальному руслі при резекціях різних об'ємів печінки, їхньої ролі у розвитку ентеральної недостатності на сьогодні досліджені недостатньо і потребують свого вирішення.

Метою дослідження було кількісне морфологічне вивчення особливостей структурної перебудови артерій порожньої кишки при пострезекційній портальній гіпертензії.

МАТЕРІАЛИ I МЕТОДИ Дослідження проведено на 36 статевозрілих щурах-самцях, яких поділили на 3 групи: перша нараховувала 12 інтактних практично здорових тварин, друга - 12 щурів після резекції лівої бокової частки - 31,5 \% паренхіми печінки, третя - 12 тварин після видалення правої та лівої бокових часток печінки (58,1 \%) [4]. Евтаназію дослідних тварин здійснювали кровопусканням в умовах тіопенталового наркозу через один місяць від початку експерименту. Усі маніпуляції та евтаназію щурів проводили з дотриманням основних принципів роботи з експериментальними тваринами відповідно до положення Європейської конвенції про захист хребетних тварин, які використовуються для експериментальних та інших наукових цілей (Страсбург, 1986 р.), Загальних етичних принципів експериментів на тваринах, ухвалених Першим національним конгресом 3 біоетики (Київ, 2001 р.), а також Закону України "Про захист тварин від жорстокого поводження" (від 21.02.2006) [5].

Вирізані шматочки із порожньої кишки фріксували в 10 \% нейтральному розчині фрормаліну і після відповідного проведення через етилові спирти зростаючої концентрації заливали у парафрінові блоки за загальноприйнятою 
методикою. Гістологічні зрізи товщиною 5-7 мкм після депарафрінізації фрарбували гематоксиліном та еозином, за ван-Гізон, Маллорі, Вейгертом, толуїдиновим синім [9]. Проводили морфометрію артерій середнього (51-125 мкм) та дрібного калібрів (26-50 мкм) порожньої кишки. При морфометрії артерій вимірювали їх зовнішній (ЗД) та внутрішній (ДВ) діаметри, товщини медії (ТМ) та адвентиції (ТА), висоту ендотеліоцитів (BE), діаметр їх ядер (ДЯЕ), визначали індекс Вогенворта (IB), ядерно-цитоплазматичні відношення в ендотеліоцитах (ЯЦВ) та відносний об'єм ушкоджених ендотеліоцитів (ВОУЕ) [1, 3, 11]. Морфометрію вказаних судин проводили за допомогою світлового мікроскопа "Olimpus BX-2" з цифровою відеокамерою та пакетом прикладних програм "Відео Тест 5,0" та "Відео розмір 5,0". Кількісні показники обробляли статистично. Обробку результатів виконано у відділі системних статистичних досліджень Тернопільського державного медичного університету імені І. Я. Горбачевського в програмному пакеті STATISTIKA. Різницю між порівнювальними величинами визначали за критерієм Стьюдента та Манна-Уїтні [6 ].

РЕЗУЛЬТАТИ ДОСЛІДЖЕНЬ ТА ЇХ ОБГОВОРЕННЯ Морфометричні параметри артерій середнього та дрібного калібрів порожньої кишки, отримані в результаті проведеного дослідження, представлені у таблиці. Усестороннім аналізом отриманих даних встановлено, що резекція 31,5 \% паренхіми печінки не призводила до вираженої структурної перебудови артерій середнього калібру порожньої кишки. У даних експериментальних умовах морфометрично встановлено тільки статистично достовірне $(p<0,01)$ зростання відносного об'єму ушкоджених ендотеліоцитів у 1,3 раза переважно за рахунок їх десквамації та апоптозу. При видаленні 58,1 \% паренхіми печінки у порожній кишці виявлялися виражені судинні розлади, які характеризувалися повнокров'ям пере- важно венозних судин. У венозній ланці гемомікроциркуляторного русла спостерігалося розширення мікросудин, повнокров'я, стази, тромбози, осередки діапедезних крововиливів. Описані вище зміни у венозному руслі порожньої кишки підтверджують наявність пострезекційної портальної гіпертензії, до якої призвело видалення 58,1 \% паренхіми печінки [4]. Артеріальні судини також у даних умовах експерименту зазнавали виражених структурних змін. Так, при цьому внутрішній діаметр артерій середнього калібру порожньої кишки з вираженою статистично достовірною різницею ( $<<0,001)$ зменшився на $12,5 \%$, висота ендотеліоцитів - на $3,1 \%(p<0,05)$ порівняно 3 контрольними величинами. Товщина медії та адвентиції артерій середнього калібру порожньої кишки в умовах даного експерименту статистично достовірно $(p<0,001)$ збільшилася відповідно на 14,7 та 30,8 \%, а індекс Вогенворта - на 35,9 \%. Зменшення просвіту даних артерій, потовщення їх стінки за рахунок зростання товщин медії та адвентиції, зростання індексу Вогенворта вказували на погіршання пропускної здатності цих судин [4, 11].

Варто також зазначити, що в ендотеліальних клітинах артерій середнього калібру порожньої кишки при видаленні 58,1 \% паренхіми печінки виражено змінювалися ядерно-цитоплазматичні відношення. Вказаний морфометричний параметр при цьому дорівнював 0,316 $\pm 0,003$ і перевищував аналогічний контрольний показник на 10,9 \% (p<0,001). 3 високою статистично достовірною різницею $(p<0,001)$ у досліджуваних експериментальних умовах в 11,3 раза зріс відносний об'єм ушкоджених ендотеліоцитів.

Артерії дрібного калібру порожньої кишки при резекції різних об'ємів печінки зазнавали структурної перебудови у більшому ступені порівняно 3 попередніми. Так, внутрішній діаметр вказаних судин при видаленні 31,5 \% паренхіми печінки статистично достовірно $(p<0,05)$ змен-

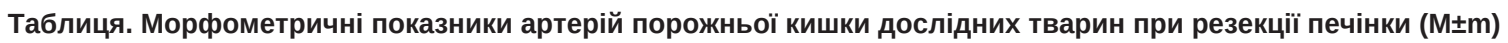

\begin{tabular}{|c|c|c|c|}
\hline \multirow{2}{*}{ Показник } & \multicolumn{3}{|c|}{ Група спостереження } \\
\hline & перша & друга & третя \\
\hline \multicolumn{4}{|c|}{ Артерії середнього калібру } \\
\hline ЗД (мкм) & $83,80 \pm 1,14$ & $84,10 \pm 1,20$ & $85,50 \pm 1,20$ \\
\hline ВД (мКм) & $51,20 \pm 0,54$ & $50,90 \pm 0,63$ & $44,80 \pm 0,51^{\text {** }}$ \\
\hline TM (мкм) & $15,60 \pm 0,18$ & $15,90 \pm 0,24$ & $17,90 \pm 0,21^{\star \star \star}$ \\
\hline TA (мКм) & $10,85 \pm 0,12$ & $11,22 \pm 0,18$ & $14.20 \pm 0,24^{\star \star \star}$ \\
\hline IB (\%) & $267,9 \pm 3,6$ & $272,9 \pm 3,9$ & $364,2 \pm 4,2^{\star \star \star}$ \\
\hline BE (мКм) & $6,15 \pm 0,07$ & $6,08 \pm 0,06$ & $5,96 \pm 0,05^{\star}$ \\
\hline ДЯЕ (мкм) & $3,30 \pm 0,04$ & $3,27 \pm 0,05$ & $3,35 \pm 0,04$ \\
\hline ЯЦВ & $0,285 \pm 0,003$ & $0,290 \pm 0,05$ & $0,316 \pm 0,003^{\star *}$ \\
\hline BOУE (\%) & $1,80 \pm 0,02$ & $2,40 \pm 0,05^{\star \star}$ & $20,40 \pm 0,33^{\star \star \star}$ \\
\hline \multicolumn{4}{|c|}{ Артерії дрібного калібру } \\
\hline ЗД (мкм) & $37,10 \pm 0,48$ & $37,35 \pm 0,45$ & $37,85 \pm 0,45$ \\
\hline ВД (мкм) & $12,40 \pm 0,15$ & $11,90 \pm 0,12^{\star}$ & $10,40 \pm 0,12^{\star \star \star}$ \\
\hline TM (мКм) & $7,80 \pm 0,09$ & $8,18 \pm 0,12^{\star}$ & $9,10 \pm 0,12^{\star \star \star}$ \\
\hline TA (МКм) & $6,80 \pm 0,03$ & $7,10 \pm 0,04^{\star \star}$ & $9.15 \pm 0,03^{* \star \star}$ \\
\hline IB (\%) & $895,30 \pm 10,89$ & $985,1 \pm 12,9$ ** & $1219,5 \pm 16,2^{\text {*** }}$ \\
\hline BE (мКм) & $5,95 \pm 0,06$ & $5,82 \pm 0,07$ & $5,38 \pm 0,06^{\star *}$ \\
\hline ДЯЕ (мкм) & $3,14 \pm 0,03$ & $3,10 \pm 0,04$ & $2,97 \pm 0,03^{\star *}$ \\
\hline ЯЦВ & $0,278 \pm 0,003$ & $0,285 \pm 0,05$ & $0,305 \pm 0,003^{\star \star *}$ \\
\hline BOУE (\%) & $2,15 \pm 0,03$ & $4,85 \pm 0,06^{\star \star *}$ & $45,90 \pm 0,63^{\text {*** }}$ \\
\hline
\end{tabular}

Примітка. * - p<0,05; ** - p<0,01; ** - p<0,001 порівняно з першою групою. 
шився на 4,0 \%. Товщина медії цих судин у досліджуваних експериментальних умовах збільшилася на 4,9\%, товщина адвентиції - 4,4 \%, індекс Вогенворта - на $10 \%$. Висота ендотеліоцитів, діаметр їх ядер, ядерно-цитоплазматичні відношення у цих клітинах суттєво не змінювалися, вказуючи на стабільність клітинного структурного гомеостазу $[1,8]$. Відносний об'єм ушкоджених ендотеліоцитів при цьому зріс у 2,25 раза $(p<0,001)$.

Через місяць після резекції 58,1 \% паренхіми печінки досліджувані моророметричні параметри артерій дрібного калібру порожньої кишки змінювалися у більшому ступені порівняно з наведеними вище показниками. Так, зовнішній діаметр даних судин виявився збільшеним на 2,0 \%. 3 високим ступенем достовірної різниці $(p<0,001)$ зросли при цьому товщини медії, адвентиції та індекс Вогенворта. Виявлене збільшення вказаних морфометричних параметрів при цьому відповідно дорівнювало 16,$7 ; 34,5$ та 36,2 \%. Просвіт артерій дрібного калібру порожньої кишки через місяць після видалення 58,1 \% паренхіми печінки статистично достовірно $(p<0,001)$ зменшився на 16,1%. Значне збільшення індексу Вогенворта, товщин медії, адвентиції та звуження просвіту досліджуваних артеріальних судин свідчили про виражене зниження їх фрізіологічної пропускної здатності $[4,11]$ та погіршення кровопостачання досліджуваного органа. Нерівномірні, диспропорційні зміни просторових характеристик ядра та цитоплазми ендотеліоцитів досліджуваних артерій через місяць після резекції 58,1 \% паренхіми печінки призводиди до виражених порушень між їхніми морфометричними параметрами, що адекватно відображали ядерно-цитоплазматичні відношення у названих клітинах. Вказаний морфометричний параметр при цьому дорівнював 0,305 $\pm 0,003$ і з вираженим ступенем статистичної достовірності $(p<0,001)$ відрізнявся від аналогічного контрольного показника на 9,7\%. Виявлені зміни ядерно-цитоплазматичних відношень свідчили про порущення структурного клітинного гомеостазу [8]. Відносний об'єм ушкоджених ендотеліоцитів у артеріях дрібного калібру порожньої кишки через місяць після видалення 58,1 \% паренхіми печінки зріс у 21,3 раза. Вираженішу структурну перебудову артерій дрібного калібру порожньої кишки в умовах змодельованого експерименту можна пояснити більшим фрункціональним навантаженням вказаних судин порівняно 3 артеріями середнього калібру $[3,11]$.
Гістологічно в оболонках стінки порожньої кишки спостерігалися виражені судинні розлади, набряки строми, осередки дистрофрічно, некробіотично, апоптично змінених епітеліоцитів, вогнищеві клітинні інфрільтрати та розростання строми. Відмічався набряк ендотеліоцитів, їх дистрофія, некробіоз, десквамація та проліферація. Остання підтверджувала наявність гіпоксії. Виявлялося просякання мембран, ендотеліоцитів, судинної стінки білками плазми. У деяких досліджуваних судинах спостерігалися осередки фрібриноїдного набряку та некрозу, що свідчило про виражене їх ушкодження.

Відомо, що ендотеліоцити судин синтезують різні біологічно активні речовини, необхідні для регуляції життєво важливих процесів організму: зсідання крові, регуляція тонусу судин, скоротливість серця, дисрузія води, іонів, продуктів метаболізму. Ендотеліоцити здійснюють бар'єрну, продукційну, гемостатичну, метаболічну, транспортну, репаративну фрункції, синтезують оксид азоту (NO). Ушкодження значної кількості ендотеліоцитів призводить до їхньої дисфункції, блокади NO-синтази, зменшення синтезу NO, активації процесів його деградації, що супроводжується спазмом та звуженням судин [7]. Останнє погіршує кровопостачання органів, призводить, підтримує та посилює гіпоксію, яка ускладнюється набряком, дистрофрією, некробіозом тканин і клітин. Наведене підтверджувалося результатами проведеного дослідження. При значному ушкодженні ендотеліоцитів ступінь морфологічних змін у стінці порожньої кишки був вираженішим.

Висновки Резекція 58,1 \% паренхіми печінки призводить до пострезекційної портальної гіпертензії та вираженої структурної перебудови артерій середнього та дрібного калібрів порожньої кишки, яка характеризується потовщенням їхньої стінки, звуженням просвіту, ураженням ендотеліоцитів, ендотеліальною диссрункцією, погіршанням кровопостачання органа, гіпоксією, дистросрією, некробізом тканин і клітин, осередками клітинних інсрільтратів, склерозуванням. Ступінь структурної перебудови артерій порожньої кишки при пострезекційній портальній гіпертензії залежить від їх калібру і найбільш вираженим виявився у досліджуваних судинах дрібного калібру.

Перспективи подальших досліджень Всебічне, адекватне вивчення структурної перебудови артеріального русла порожньої кишки в умовах пострезекційної портальної гіпертензії дозволить суттєво розширити діагностику, корекцію та профрілактику досліджуваної патології.

\section{СПИСОК ЛІТЕРАТУРИ}

1. Автандилов Г. Г. Основы количественной патологической анатомии / Г. Г. Автандилов. - М. : Медицина, 2002. - 240 с.

2. Вишневський В. А. Сегментарные резекции, отдаленные результаты при злокачественных опухолях печени / В. А. Вишневский, М. Г. Ефранов, И. В. Казаков // Укр. журнал хірургії. 2012. - № 1 (16). - С. 5-15.

3. Гнатюк М. С. Морфометрична оцінка вікових особливостей ремоделювання артерій дванадцятипалої кишки / М. С. Гнатюк, Л. В. Татарчук, М. В. Данів // Клінічна анатомія та оперативна хірургія. - 2009. - Т. 8, № 4. - С. 54-57.

4. Гнатюк М. С. Морфометрична оцінка особливостей ремоделювання структур дванадцятипалої кишки при резекції різних об'ємів печінки / М. С. Гнатюк, Л. В. Татарчук, О.Б.Ясіновський // Науковий вісник Ужгородського університету. Серія "Медицина". - 2016. - Вип. 1 (53). - С. 92-95.
5. Загальні етичні принципи експериментів на тваринах // Ендокринологія. - 2003. - Т. 8, № 1. - С. 142-145.

6. Лапач С. Н. Статистические методы в медико-биологических исследованиях Excell / С. Н. Лапач, А. В. Губенко, П. Н. Бабич. - К. : Морион, 2001. - 410 c.

7. Макаров М. А. Роль диссрункции эндотелия и регидности артерій в патогенезе хронической обструктивной болезни легких I М. А. Макаров, С. Н. Авдеев, А. Г. Чучалин // Терапевтический архив. - 2012. - № 3. - С. 74-80.

8. Саркисов Д. С. Структурне основы адаптации и компенсации нарушенных фрункций / Д. С. Саркисов. - М. : Медицина, 1998. - 230 c.

9. Сорочинников А. Г. Гистологическая и микроскопическая техника / А. Г. Сорочинников, А. Е. Доросевич. - М. : Медицина. $-2007 .-448 \mathrm{c}$. 
10. Основные осложнения обширных резекций печени и пути их предупреждения / В. Д. Федоров, В. А. Вишневский, Н. А. Назаренко [и др.] // Бюлл. сибирской медицины. - 2007. № 4. - C. 16-24.

11. Шорманов С. В. Гистологические и ультраструктурные изменения печени при экспериментальном стенозе легочного ствола на стадии декомпенсации / С. В. Шорманов, С. В. Куликов // Морфология. - 2010. - № 3. - С. 46-50.

12. Nanashima A. A modified grading system for post-hepatectomy metastatic liver cancer originating form colorectal carcinoma / A. Nanashima, Y. Sumida, T. Abo // J. Surg. Oncol. - 2008. No. 98. - P. 363-370.

\section{QUANTITATIVE MORPHOLOGICAL EVALUATION OF STRUCTURAL RECONSTRUCTION OF ARTERIES OF JEJUNUM AT POSTRESECTION PORTAL HYPERTENSION}

Summary. Liver resection is widely used in modern surgical departments. Removal of large sizes of the liver leads to postresection portal hypertension, which is complicated by bleeding from varicose veins of the esophagus, stomach, rectum, ascites, splenomegaly with secondary hyperpselinism, parenchymal jaundice and portosystemic encephalopathy. The widespread prevalence of this pathology, high mortality from its complications indicates that it is an important medical and social problem.

The aim of the study - quantitative morphological study of the features of the structural reconstruction arteries of jejunum after postresection portal hypertension.

Materials and Methods. The studies were conducted on 36 sexually mature male rats, which were divided into 3 groups. The group 1 consisted of 12 intact virtually animals, $2-12$ rats after resection of the left lateral part - $31.5 \%$ of the parenchyma of the liver, 3 - 12 rats after removing of the right and left lateral portions of the liver (58.1\%). Euthanasia of experimental animals was carried out by bloodletting in conditions of thiopental anesthesia 1 month after the beginning of the experiment. From the jejunum histological preparations were made. The morphometry of arteries of middle (51-125) microns and small calibers (26-50) microns of jejunum was measured, in which their external and internal diameters, the thickness of the media and adventitia, the height of the endothelial cells, the diameter of their nuclei were determined the Wogenworts index, the nuclear-cytoplasmic rations in the endothelial cells and the relative volume of damaged endothelial cells. Quantitative indicators were processed statistically.

Results and Discussion. It was established that after resection of $31.5 \%$ of the liver parenchyma, the morphometric indices of the arteries of the middle and small arteries of the jejunum were insignificantly changed. When removing $58.1 \%$ of liver parenchyma, a marked structural reconstruction of the arterial bed with the predominance of morphological changes in the arteries of small caliber. One month after the removing of $58.1 \%$ of the liver parenchyma, the outer diameter of the small caliber arteries increased by $2.0 \%$, the thickness of the media - by $16.7 \%$, the thickness of the adventitia - by $34.5 \%$, the Wogenworts index - 1.4 times, indicating on a significant structural reconstruction of the examined vessels. The inner diameter of small-caliber arteries with a significant statistical significance $(p<0.001)$ decreased by $16.1 \%$. The height of the endothelial cells of the vessels was changed by $9.6 \%$, and their nuclei - by $5.4 \%(p<0.01)$. The nuclear-cytoplasmic relations in the endothelial cells of the studied arteries were significantly disturbed, indicating a violation of cellular structural homeostasis, while the relative volume of damaged endothelial cells increased by 23.4 times. The studies shows the significantly remodeling of the arteries of the jejunum after the removing of $58.1 \%$ of the parenchyma of the liver, which leads to deterioration of blood supply to the organ, hypoxia, dystrophy, necrobiosis of cells and tissues, and later infiltrative and sclerotic processes.

Conclusions. Resection of $58.1 \%$ of liver parenchyma leads to postresection portal hypertension and marked structural reconstruction of middle and small caliber arteries of the jejunum, which was characterized by thickening of their walls, narrowing of the lumen, endothelial cell lesion, endothelial dysfunction, deterioration of blood supply to the organ, hypoxia, dystrophy, necrobiosis of cells and tissues, focal cell infiltrates, and sclerosis. The degree of structural reconstruction of arteries of the jejunum after postresection portal hypertension depends on their caliber and the most pronounced was found in investigated vessels of small caliber.

Key words: resection of liver; jejunum; structure of arteries; morphometry.

\section{КОЛИЧЕСТВЕННАЯ МОРФОЛОГИЧЕСКАЯ ОЦЕНКА СТРУКТУРНОЙ ПЕРЕСТРОЙКИ АРТЕРИЙ ТОЩЕЙ КИШКИ ПРИ} ПОСТРЕЗЕКЦИОННОЙ ПОРТАЛЬНОЙ ГИПЕРТЕНЗИИ

Резюме. Резекция печени широко производится у современных хирургических отделениях. Удаление больших объемов печени осложняется пострезекционной портальной гирентензией, что приводит к кровотечениям с варикозно расширенных вен пищевода, желудка, прямой кишки, асциту, спленомегалии, вторичному гиперспленизму, паренхиматозной желтухе и портосистемной энцефалопатии. Широкое распространение данной патологии, високая летальность от ее осложнений свидетельствуют, что она есть важной медицинской и социальной проблемой.

Цель исследования - количественное морфологическое изучение особенностей структурной перестройки артерий тощей кишки при пострезекционной портальной гипертензии.

Материалы и методы. Исследования проведены на 36 половозрелых крысах-самцах, которых разделили на 3 группы: первая группа включала 12 интактных практически здоровых животных, вторая - 12 крыс после резекции левой боковой части - 31,5 \% паренхимы печени, третья - 12 животных после удаления правой и левой боковых частей печени (58,1 \%). Эвтаназия животных осуществлялась кровопусканием в условиях тиопенталового наркоза через месяц от начала эксперимента. Из 
ISSN 1681-276Х. ВІСНИК НАУКОВИХ ДОСЛІДЖЕНЬ. 2018. № 1

тощей кишки изготовляли гистологические микроперпараты. Проводили морфометрию артерий среднего (51-125 мкм) и мелкого (26-50 мкм) калибров, при которой измеряли их внешний, внутренний диаметры, толщины медии, адвентиции, высоту эндотелиоцитов, диаметр их ядер, определяли индекс Вогенворта, ядерно-цитоплазматические отношения в эндотелиоцитах, относительный объем поврежденных эндотелиоцитов. Количественные показатели обрабатывали статистически.

Результаты исследований и их обсуждение. Выявлено, что при резекции 31,5 \% паренхимы печени исследуемые морфометрические показатели артерий среднего и мелкого калибров тощей кишки изменялись незначительно. При удалении 58,1 \% паренхимы печени виявлена выраженная структурная перестройка артериального русла с доминированием морфологических изменений артерий мелкого калибра тощей кишки. Через месяц после удаления 58,1 \% паренхимы печени внешний диаметр артерий мелкого калибра увеличился на 2,0 \%, толщина медии - на 16,7 \%, толщина адвентиции - на 34,5\%, индекс Вогенворта - в 1,4 раза, свидетельствуя о существенном нарушении пропускной возможности исследуемых сосудов. Просвет артерий мелкого калибра при этом с выраженной статистической достоверностью (p<0,001) уменьшился на 16,1 \%. Высота эндотелиоцитов этих сосудов виявилась измененной на 9,6 \%, а диаметр ядер - на $5,4 \%(p<0,01)$. Ядерно-цитоплазматические отношения в эндотелиоцитах исследуемых артерий выявились существенно измененными, что свидетельствовало о нарушении клеточного структурного гомеостаза, а относительный объем поврежденных эндотелиоцитов при этом увеличился у 21,3 раза. Наведенное указывало о выраженном ремоделировании артерий тощей кишки при удалении 58,1 \% паренхимь печени, которое приводит к ухудшению кровоснабжения органа, гипоксии, дистрофии, некробиоза клеток и тканей, а позднее к инфильтративным и склеротическим процессам.

Выводы. Резекция 58,1 \% паренхимы печени приводит к пострезекционной портальной гипертензии и выраженной структурной перестройке артерий среднего и мелкого калибров тощей кишки, которая характеризуется утолщением ихней стенки, сужением просвета, повреждением эндотелиоцитов, эндотелиальной диссункцией, ухудшением кровоснабжения органа, гипоксией, дистрофией, некробиозом тканей и клеток, очаговыми клеточными инфильтратами, склерозированием. Степень структурной перестройки артерий тощей кишки при пострезекционной портальной гипертензии зависит от их калибра и наиболее выраженной выявилась у исследуемых сосудах мелкого калибра.

Ключевые слова: резекция печени; тощая кишка; структура артерій; морфометрия. 